DOI: $10.31393 /$ reports-vnmedical-2021-25(4)-07

UDC: $616.379-008.64: 577.112: 616.61-07-084$

\title{
INDICATORS OF SEVERITY AND ACCENTUATED PERSONALITY TRAITS IN MEN WITH VARIOUS FORMS OF ECZEMA
}

\section{Al-Omary Ala'a Osama Ahmad}

National Pirogov Memorial Medical University, Vinnytsya (Pyrogov street 56, Vinnytsya, Ukraine, 21018)

Responsible for correspondence: e-mail: alaaalomari33@yahoo.com

Received: September, 22, 2021; Accepted: October, 21, 2021

Annotation. The purpose of this work is to determine the features of indicators of severity and features of accentuated personality traits in men with various forms of eczema. On the basis of the Military Medical Clinical Center of the Central Region and the Department of Dermatology and Venereal Diseases with a postgraduate course in National Pirogov Memorial Medical University, Vinnytsya, a survey of men of the first adult age (22-35 years) with true ( $n=34$, including 16 with mild and 18 with severe course) and microbial ( $n=38$, including 28 with mild and 10 with severe course) eczema was conducted. The diagnosis of eczema was performed according to the nomenclature of ICD-10. All men with the help of personality questionnaires were assessed by the severity and features of accentuated personality traits by Shmishek. Statistical data processing was performed in the license package "Statistica 5.5" using non-parametric methods of evaluation of the obtained results. The control group of subjects revealed the following percentage distribution of types of accentuation: hyperthymic - in $37.80 \%$; stuck - in $1.22 \%$; emotional - in $1.22 \%$; pedantic - in 3.66 $\%$; anxious - in $1.22 \%$; cyclothymic - in $10.98 \%$; demonstrative - in $3.66 \%$; excitable - in $7.32 \%$; dysthymic - in $0 \%$; exalted type in $14.63 \%$. In patients with true eczema of mild course: hyperthymic - in $43.75 \%$; stuck - in $0 \%$; emotional - in $0 \%$; meticulous - in $0 \%$; anxious - in $0 \%$; cyclothymic - in 0\%; demonstrative - in $6.25 \%$; excitable - in 0\%; dysthymic - in $6.25 \%$; exalted type - $6.25 \%$. In patients with true eczema of severe course: hyperthymic - in $83.33 \%$; stuck - in 0\%; emotional - in 0\%; meticulous - $5.56 \%$; anxious - in $0 \%$; cyclothymic - in $0 \%$; demonstrative - in $5.56 \%$; excitable - in 0\%; dysthymic - in 0\%; exalted type - in $11.11 \%$. In patients with mild microbial eczema: hyperthymic - in $53.57 \%$; stuck - in $0 \%$; emotional - in $0 \%$; meticulous - in $7.14 \%$; anxious - in $0 \%$; cyclothymic - in $3.57 \%$; demonstrative - in $0 \%$; excitable - in $7.14 \%$; dysthymic - in 0\%; exalted type - in $7.14 \%$. In patients with severe microbial eczema: hyperthymic - in $40.00 \%$; stuck - in $0 \%$; emotional - in $0 \%$; meticulous - $10.00 \%$; anxious - in $0 \%$; cyclothymic - in $0 \%$; demonstrative - in $0 \%$; excitable - in 0\%; dysthymic - in $0 \%$; exalted type - $10.00 \%$. Thus, the active use in everyday practice of interviewing and psychological testing of character accentuation are the most important components of adequate assessment of psycho-emotional status of patients with various forms and severity of eczema, which opens prospects for psychoprophylaxis and finding the right ways of correction. Thus, in patients with different forms and severity of eczema, the predominance of accentuation of the nature of the hyperthymic type was established. This allows us to consider this type of accentuation as one of the important criteria for assessing the patient's motivation to see a dermatologist and adherence to treatment, to identify weaknesses in his character, to predict factors that can cause decompensation or psychogenic reactions accompanied by maladaptation.

Keywords: true eczema, microbial eczema, accentuations of character according to Shmishek.

\section{Introduction}

Currently, there is a growing interest in research to study the individual psychological characteristics of patients with various dermatoses. It is important to study the peculiarities of the patient's perception of his position depending on the disease in the context of its value systems, capabilities, plans, etc. [1, 3, 2, 14]. Intense pace of life, increasing emotional load requires significant nervous and intellectual effort. These are the so-called "scissors" that occur between a person's natural adaptive capacity and living conditions, which leads to an increase in the incidence of chronic dermatoses, among which eczema occupies a prominent place [15].

Studies conducted in our country are aimed primarily at studying the influence of psycho-emotional factors in prolonged forms of dermatosis, as well as the development of methods of psychotherapeutic and pharmacological correction of these disorders [8, 10, 12]. Foreign colleagues mainly treat eczema in terms of classical psychosomatics. This is dermatosis, which is based on a bodily reaction to the conflict experience, associated with morphologically established changes and pathological disorders in the skin and its derivatives [2, 7, 13]. Analysis of these literature sources allows us to conclude about the different interpretation of the nature of psycho-personal changes in patients with eczema. However, from whatever perspective we look at this issue, it is important to remember that underestimating the mental state of patients can lead to unwarranted prescribing of medications and procedures. And if you do not take into account the emotional factor in skin diseases, the nature of the patients, then for most of them therapeutic care will be ineffective.

The purpose of the work - to determine the features of indicators of severity and features of accentuated personality traits in men with various forms of eczema.

\section{Materials and methods}

On the basis of the Military Medical Clinical Center of the Central Region and the Department of Dermatology and Venereal Diseases with a postgraduate course in National Pirogov Memorial Medical University, Vinnytsya, a 
survey of men of the first adult age (22-35 years) with true ( $n=34$, including 16 with mild and 18 with severe course) and microbial $(\mathrm{n}=38$, including 28 with mild and 10 with severe course) eczema was conducted.

The diagnosis of eczema was performed according to the nomenclature ICD-10 (https://zakononline.com.ua/ documents/show/116857_531218). All men with the help of personality questionnaires were assessed by the severity and features of accentuated personality traits by Shmishek [4].

Statistical data processing was performed in the license package "Statistica 5.5" using non-parametric methods of evaluation of the obtained results. The reliability of the difference between the values between the independent quantitative values was determined using the MannWhitney U-test.

\section{Results. Discussion}

In working with the patient, the doctor should rely on such personality traits that are invariable and relatively stable. It is important to know not so much the typology of the attitude to treatment, as the typology of the patient's personality and his character. Character, as we know, is a personal ground, a stable property of the individual, which is inherited, not formed in the process of socialization [6, 16].

Among the existing approaches and typologies that are quite correct to use in the daily practice of the doctor, we can consider the typology of Karl Leonhard "Accentuated personalities", which was formulated by its author, taking into account the vast experience in the clinic of neurosis. Shmishek's personal questionnaire is a valid and reliable method of diagnosing character accentuations, which can be used by a doctor at the same time as determining by external manifestations to which type of character accentuation a patient can be assigned. K. Leonhard described 12 types of character accentuations: demonstrative, stuck, meticulous, exciting, hyperthymic, dysthymic, anxious, cyclothymic, exalted, emotional, extroverted and introverted [5, 11].

We analyzed the results of determining the characteristics of indicators of severity and features of accentuated personality traits in men with various forms of eczema. We found that:

- the rate of accentuation of the character of the hyperthymic type according to Shmishek was significantly $(p<0.05-0.01)$ higher in patients with true eczema of severe course (21.00 \pm 2.30 points) compared with the control group (17.45 \pm 4.52 points), patients with true eczema of mild course (14.80 \pm 8.37 points) and microbial eczema of severe course (18.30 \pm 2.98 points);

- the percentage of persons with no accentuation of character by hyperthymic type was significantly $(p<0.05$ 0.01 ) lower in patients with true eczema of severe course $(0 \%)$ compared with healthy subjects $(23.17 \%)$, patients with true $(37.5 \%)$ and microbial $(21.43 \%)$ eczema of mild course. The percentage of persons with the presence of character accentuation by hyperthymic type was significantly $(p<0.05-0.001)$ higher in patients with true eczema of severe course $(83.33 \%)$ compared with healthy subjects $(37.80$ $\%)$, patients with true (43.75\%) and microbial (53.57\%) eczema of mild course and microbial eczema of severe course $(40.0 \%)$;

- the rate of accentuation of the nature of the stuck type according to Shmishek is significantly $(p<0.05)$ higher in patients with true eczema of severe course $(14.00 \pm 2.47$ points) compared with patients with true eczema of mild course (11.73 \pm 2.71 points.);

- the rate of accentuation of the character of the anxiety type according to Shmishek is significantly $(p<0.01)$ lower in patients with true eczema of severe course $(5.333 \pm 2.196$ points) compared with the control group (9.220 \pm 5.493 points) and tends to lower values compared with patients on the truth of eczema of mild course $(8.533 \pm 4.838$ points);

- the percentage of people with no character accentuation by anxiety type is significantly $(\mathrm{p}<0.05-0.01)$ higher in patients with true severe eczema (100\%) compared with healthy subjects $(76.83 \%)$ and tends $(p=0.063-0.060)$ to higher values of patients with true $(81.25 \%)$ and microbial (89.29 \%) eczema of mild course;

- the rate of accentuation of the character of the cyclothymic type according to Shmishek was significantly $(p<0.05$ in both cases) higher in the control groups (12.29 \pm 3.91 points) compared with patients with true eczema (11.78 \pm 3.62 points). and severe microbial eczema (10.60 \pm 2.99 points);

- the percentage of people with no accentuation of character by anxiety type was significantly $(\mathrm{p}<0.05$ in all cases) higher in patients with true $(83.33 \%)$ and microbial $(90.0 \%)$ severe eczema compared with healthy subjects (53.66\%);

- the rate of accentuation of the character of the excitable type according to Shmishek was significantly $(p<0.01$ $0.001)$ higher in the control groups $(12.40 \pm 5.27$ points) compared with patients with true eczema $(7.533 \pm 3.944$ points) and microbial eczema ( $8.464 \pm 4.903$ points) of mild course and true eczema (6.833 \pm 4.091 points) and microbial eczema (6.900 \pm 5.109 points) of severe course;

- the percentage of persons with no accentuation of the character of the excitable type is significantly $(\mathrm{p}<0.05-$ $0.001)$ higher in patients with true eczema of mild $(87.5 \%)$ and severe $(100 \%)$ course, patients with microbial eczema of the mild $(89.29 \%)$ and severe $(90.0 \%)$ course compared with healthy subjects $(54.88 \%)$;

- the percentage of people with no accentuation of the character on the demonstrative type is significantly $(p<0.05-$ 0.001 ) lower in patients with true eczema of mild course $(68.75 \%)$ compared with healthy subjects $(90.24 \%)$ and patients with microbial eczema of mild course $(96.43 \%)$ and tends to $(p=0.058-0.061)$ lower values compared with patients with true $(94.44 \%)$ and microbial (100\%) severe eczema. The percentage of people with the presence of 
character accentuation by the demonstrative type was significantly $(p<0.05)$ higher in patients with true eczema of mild $(6.25 \%)$ course compared with healthy subjects $(0 \%)$.

According to the indicator of accentuation of the character of emotional, pedantic, demonstrative, dysthymic and exalted type, no significant differences and tendencies of differences were established between different groups of subjects.

The control group of subjects revealed the following percentage distribution of types of accentuation: hyperthymic - in $37.80 \%$; stuck - in $1.22 \%$; emotional - in $1.22 \%$; pedantic - in $3.66 \%$; anxious - in $1.22 \%$; cyclothymic - in $10.98 \%$; demonstrative - in $3.66 \%$; excitable - in 7.32 $\%$; dysthymic - in $0 \%$; exalted type - in $14.63 \%$.

In patients with true eczema of mild course: hyperthymic - in $43.75 \%$; stuck - in $0 \%$; emotional - in $0 \%$; meticulous - in $0 \%$; anxious - in $0 \%$; cyclothymic - in $0 \%$; demonstrative - in $6.25 \%$; excitable - in $0 \%$; dysthymic - in $6.25 \%$; exalted type $-6.25 \%$.

In patients with true eczema of severe course: hyperthymic - in $83.33 \%$; stuck - in $0 \%$; emotional - in $0 \%$; meticulous - $5.56 \%$; anxious - in $0 \%$; cyclothymic - in $0 \%$; demonstrative - in $5.56 \%$; excitable - in $0 \%$; dysthymic - in $0 \%$; exalted type - in $11.11 \%$.

In patients with mild microbial eczema: hyperthymic - in $53.57 \%$; stuck - in $0 \%$; emotional - in $0 \%$; meticulous - in $7.14 \%$; anxious - in $0 \%$; cyclothymic - in $3.57 \%$; demonstrative - in $0 \%$; excitable - in $7.14 \%$; dysthymic - in $0 \%$; exalted type - in $7.14 \%$.

In patients with severe microbial eczema: hyperthymic in $40.00 \%$; stuck - in $0 \%$; emotional - in $0 \%$; meticulous $10.00 \%$; anxious - in $0 \%$; cyclothymic - in $0 \%$; demonstrative - in $0 \%$; excitable - in $0 \%$; dysthymic - in 0

\section{References}

[1] Burroni, A. G., Fassino, M., Torti, A., \& Visentin, E. (2015). How do disease perception, treatment features, and dermatologistpatient relationship impact on patients assuming topical treatment? An Italian survey. Patient related outcome measures, 6, 9-17. doi: 10.2147/PROM.S76551

[2] Dalgard, F. J., Gieler, U., Tomas-Aragones, L., Lien, L., Poot, F., Jemec, G. B., ... \& Kupfer, J. (2015). The psychological burden of skin diseases: a cross-sectional multicenter study among dermatological out-patients in 13 European countries. Journal of Investigative Dermatology, 135(4), 984-991. doi: 10.1038/ jid.2014.530

[3] Efremov, L., Petrusevska, A., Dimitrievska, V., \& Simonovska, V. (2021). Factors Underlying Perceptions of Quality of Life Among Acne Patients in RN Macedonia. Journal of Health and Medical Sciences, 4(1), 23-28. doi: 10.31014/ aior.1994.04.01.152

[4] Eliseev, О.Р. (2017). Практикум по психологии личности : учеб. пособие для бакалавриата и магистратуры (4-е изд., перераб. и доп.) [Workshop on personality psychology: textbook. manual for undergraduate and graduate programs (4th edition, revised and enlarged)]. М.: Издательство Юрайт - M.: Izdatel'stvo Yurajt.

[5] Furgel, I. (2014). Cognition \& Knowledge. Dr. Igor Furgel: Deutsche Nationalbibliothek.

[6] Gardini, S., Cloninger, C. R., \& Venneri, A. (2009). Individual differences in personality traits reflect structural variance in
$\%$; exalted type - $10.00 \%$.

Thus, the predominance of accentuation of the character of the hyperthymic type among the studied all comparison groups was established. This type of character accentuation is characterized by restlessness, mobility, sociability and restlessness, high spirits. The desire to be active is combined with frivolity and indiscipline. In the case of the disease, hyperthymic individuals do not consult a doctor for a long time and believe that the disease will pass itself, they do not have time for treatment. When they get to the hospital, they cannot sit still for a long time, do not follow the regime and silence in the ward, entertain and encourage others [9]. Knowledge of these personality traits of patients with eczema allows you to properly build a conversation and relationship with him, determine the nature of the internal picture of the disease and plan psychotherapeutic tactics.

\section{Conclusions and prospects for further development}

1. In patients with different forms and severity of eczema, the predominance of accentuation of the nature of the hyperthymic type was established. This allows us to consider this type of accentuation as one of the important criteria for assessing the patient's motivation to see a dermatologist and adherence to treatment, to identify weaknesses in his character, to predict factors that can cause decompensation or psychogenic reactions accompanied by maladaptation.

The conducted researchers are theoretical basis for the development of a comprehensive treatment of eczema with the correction of the psychological state of patients.

specific brain regions. Brain research bulletin, 79(5), 265270. doi: 10.1016/j.brainresbull.2009.03.005

[7] Gieler, U., Gieler, T., Peters, E. M. J., \& Linder, D. (2020). Skin and Psychosomatics-Psychodermatology today. JDDG: Journal der Deutschen Dermatologischen Gesellschaft, 18(11), 12801298. doi: $10.1111 /$ ddg.14328

[8] Kaliuzhna, L. D., \& Petrenko, A. V. (2020). Свербіж - це не тільки атопічний дерматит [Itching is not just atopic dermatitis]. Asthma and allergy, 4, 48-52. doi: 10.31655/23073373-2020-4-48-52

[9] Karam, E. G., Salamoun, M. M., Yeretzian, J. S., Mneimneh, Z. N., Karam, A. N., Fayyad, J., ... \& Akiskal, H. S. (2010). The role of anxious and hyperthymic temperaments in mental disorders: a national epidemiologic study. World Psychiatry, 9(2), 103110. doi: 10.1002/j.2051-5545.2010.tb00287.x

[10] Kutasevych, Ya. F., Oliinyk, I. O., Mashtakova, I. O., Stulii, O. M., \& Piatykop, І. О. (2019). Психосоматичні розлади у хворих на алергодерматози та їх корекція [Psychosomatic disorders in patients with allergodermatoses and their correction]. Дерматологія та венерологія - Dermatology and venereology, 1, 28-32. doi: 10.33743/ 2308-1066-20191-28-32

[11] Leonhard, K., \& Personlichkeiten. A. (1976). Auflage. Berlin.

[12] Liakhovska, N. V., Sakevych, V. D., Tymchuk, L. Iu., \& Liakhovskyi, V. I. (2021). Гетерогенність чинників, що впливають на розвиток алергічних захворювань 
[Heterogeneity of factors influencing the development of allergic diseases]. Вісник проблем біології і медицини Bulletin of problems of biology and medicine, 1(159), 292-297. doi: 10.29254/2077-4214-2021-1-159-292-297

[13] Peters, E. M. (2016). Stressed skin? - a molecular psychosomatic update on stress-causes and effects in dermatologic diseases. JDDG: Journal der Deutschen Dermatologischen Gesellschaft, 14(3), 233-252. doi: 10.1111/ ddg. 12957

[14] Sampogna, F., Tabolli, S., Giannantoni, P., Paradisi, A., \& Abeni, D. (2016). Relationship between psychosocial burden of skin conditions and symptoms: measuring the attributable fraction.
Acta dermato-venereologica, 96(1), 60-63. doi: 10.2340/ 00015555-2094

[15] Silverwood, R. J., Forbes, H. J., Abuabara, K., Ascott, A., Schmidt, M., Schmidt, S. A., ... \& Langan, S. M. (2018). Severe and predominantly active atopic eczema in adulthood and long term risk of cardiovascular disease: population based cohort study. BMJ, 361, k1786. doi: 10.1136/bmj.k1786

[16] Zentner, M., \& Shiner, R. L. (2012). Fifty years of progress in temperament research: A synthesis of major themes, findings, and challenges and a look forward. Handbook of temperament (pp. 673-700). The Guilford Press.

\section{ОСОБЛИВОСТІ ПОКАЗНИКІВ ВИРАЖЕНОСТІ ТА ОСОБЛИВОСТЕЙ АКЦЕНТУЙОВАНИХ РИС ОСОБИСТОСТІ У ЧОЛОВІКІВ ХВОРИХ НА РІЗНІ ФОРМИ ЕКЗЕМИ \\ Аль-Омарі Ала'а Осама Ахмад}

Анотація. Мета роботи - визначити особливості показників вираженості та особливостей акцентуйованих рис особистості у чоловіків хворих на різні форми екземи. На базі Військово-медичного клінічного центру Центрального регіону та кафредри шкірних і венеричних хвороб з курсом післядипломної освіти Вінницького національного медичного університету ім. М. І. Пирогова, проведено обстеження чоловіків першого зрілого віку (22-35 років) хворих на істину ( $n=34$, серед яких 16 із легким перебігом i 18 із тяжким перебігом) та мікробну ( $n=38$, серед яких 28 із легким перебігом і 10 із тяжким перебігом) екзему. Встановлення діагнозу екземи проводили згідно номенклатури МКХ-10. Усім чоловікам за допомогою особистісних опитувальників проведено оцінку вираженості і особливості акцентуйованих рис особистості за Шмішеком. Статистичну обробку даних проведено в ліцензійному пакеті "Statistica 5.5" із використанням непараметричних методів оцінки отриманих результатів. У контрольної групи досліджуваних виявлено наступний відсотковий розподіл типів акцентуації: гіпертимний - у 37,80 \%; застрягаючий - у 1,22 \%; емотивний - у 1,22 \%; педантичний - у 3,66 \%; тривожний - у 1,22 \%; циклотимний - у 10,98 \%; демонстративний - у 3,66 \%; збудливий - у 7,32 \%; дистимний - у 0\%; екзальтованого типу - у 14,63 \%. У хворих на істину екзему легкого перебігу: гіпертимний - у 43,75\%; застрягаючий - у 0 \%; емотивний - у 0 \%; педантичний - у $0 \%$; тривожний - у $0 \%$; циклотимний - у $0 \%$; демонстративний - у 6,25\%; збудливий - у $0 \%$; дистимний - у 6,25\%; екзальтованого типу - у 6,25 \%. У хворих на істину екзему тяжкого перебігу: гіпертимний - у 83,33 \%; застрягаючий - у 0 \%; емотивний - у 0 \%; педантичний - у 5,56 \%; тривожний - у $0 \%$; ииклотимний - у $0 \%$; демонстративний - у 5,56 \%; збудливий - у 0 \%; дистимний - у 0 \%; екзальтованого типу - у 11,11\%. У хворих на мікробну екзему легкого перебігу: гіпертимний - у 53,57 \%; застрягаючий - у 0 \%; емотивний - у 0 \%; педантичний - у 7,14 \%; тривожний - у 0 \%; циклотимний - у 3,57 \%; демонстративний - у 0 \%; збудливий - у 7,14\%; дистимний - у 0 \%; екзальтованого типу - у 7,14 \%. У хворих на мікробну екзему тяжкого перебігу: гіпертимний - у 40,00 \%; застрягаючий - у 0 \%; емотивний - у 0 \%; педантичний - у 10,00 \%; тривожний - у $0 \%$; циклотимний - у $0 \%$; демонстративний - у $0 \%$; збудливий - у $0 \%$; дистимний - у $0 \%$; екзальтованого типу - у 10,00 \%. Таким чином, активне використання у повсякденній практиці інтерв'ювання та психологічного тестування акцентуації характеру є найважливішими компонентами адекватної оцінки психоемоційного статусу пацієнтів з різними формами і ступенем тяжкості екземи, що відкриває перспективи психопрофрілактики та пошуку правильних шляхів корекції. Отже, у хворих з різними формами та ступенем тяжкості екземи встановлено переважання акцентуації характеру гіпертимного типу. Це дозволяє розглядати даний тип акцентуації як один із важливих критерії оцінки мотивації звернення пацієнта до дерматолога та прихильності до лікування, визначити слабкі місия його характеру, передбачати фрактори, які здатні викликати декомпенсації або психогенні реакції, що супроводжуються дезадаптацією.

Ключові слова: істина екзема, мікробна екзема, акцентуації характеру за Шмішеком. 